\title{
Energy security: between markets and sovereign politics
}

\author{
Radu DUDAU \\ Bucharest University, Bucharest, Romania \\ Alexandra Catalina NEDELCU \\ The Bucharest University of Economic Studies, Bucharest, Romania \\ catalina.nedelcu@fabiz.ase.ro
}

\begin{abstract}
Energy security is a constant presence in the energy-related political discourse all over the world. States strive to secure steady inflows of needed energy supplies, as well as the price affordability of those supplies. However, what are deemed to be the best means to meet such goals depends on one's theoretical vantage point. On the one hand, economically-minded theorists maintain that energy security is only a matter of market rules and interactions. Thus, they call upon energy markets to deliver both steady supplies and competitive prices. On the other hand, politically-minded scholars emphasize the political and hard-power nature of international energy trades, especially in a global context market by the emergence of statecentered, authoritarian regimes that use large national energy companies as foreign policy instruments. These two positions delineate competing approaches to how energy security risks ought to be managed. The former approaches energy security risks by means similar to portfolio management, requiring diversification of investments in order to insulate them from market shocks. The latter approaches energy security as a matter of foreign policy, by which states envisage interest coordination and favorable alignments within countervailing alliances against the agent of energy security risk. The present paper goes beyond the uncontentious point that these two dimensions are complementary. It argues that, depending on the international context, a more market-driven or a more-politically driven behavior may be adequate.
\end{abstract}

Keywords: energy security, foreign policy, security of supply, energy market.

Please cite the article as follows: Dudau, R. and Nedelcu, A.C. (2016), "Energy security: between markets and sovereign politics", Management \& Marketing. Challenges for the Knowledge Society, Vol. 11, No. 3, pp. 544-552. DOI: 10.1515/mmcks-2016-0015

\section{Introduction}

Energy security is a common strategic objective in the energy policy of states. For net importing countries, it refers in the first place to the security of energy supply, which in turn has to do with a state's ability to secure the needed energy imports from various sources and through various conduits at an affordable price. For net energy exporting countries, energy security designates rather the state's ability to secure and maintain market share.

Either way, there is an intrinsic political element to energy security, as international energy trade puts producer, transit, and consumer countries in relations of mutual (though not necessarily symmetrical) dependence, which are prone to being 
politically instrumentalized. Besides, as Shaffer (2009, p. 3) notices with respect to the international oil trade,

"Energy use affects the structure of the international system itself: oil use creates an element of interdependency in the international system. Since oil is a global commodity, each country's demand affects the price and supply availability of oil for all consumers."

Seen from the vantage point of the main actors at the international level (states, organizations and corporations), one paradigmatic approach to energy security is the market-driven one, which relies on inclusive, competitive and transparent international markets for ready access to energy. In a market-based environment, both pricing and flows of energy are optimized through the unhindered equilibrium of supply and demand. Accordingly, energy becomes a foremost commodity, delivered by profit seeking suppliers, and energy security risks are managed similarly to portfolio management on the capital markets (der Linde, 2008), with portfolio diversification and hedging contracts as instruments of risk mitigation.

As a matter of fact, the radicals in this camp, such a Pierre Noel (2008), dismiss the concept of energy security altogether, arguing that energy trade is shaped by market forces alone, with no substantive role to play for politics and geopolitics. There is a naïve ring to this claim, unless one reads it as implying that, in spite of the appearances, state action in the energy realm, domestically and internationally, is ultimately shaped by market fundamentals.

Obviously, the market-driven approach to energy security relies on a number of idealizations: it assumes an economic environment readily responsive to price signals, low barriers to international energy trade, sufficient infrastructure capacity, as well as widely accepted norms, rules, and procedures that regulate investments, contracts, conflict resolution etc. As such, it approximates to a large extent the liberal view of free trade, with competitive energy markets reinforcing robust and efficient supply mechanisms. As shown in the next section, the market-driven regime of international energy trade was in place in the 1990s for less than a decade of functional quasi-purity, anchored in a broad international consensus. For the rest, it either displayed familiar practices of oligopolistic market and price control, or has taken strokes from the rivaling state-centered, geo-politicized approach to international energy trade.

In a countervailing simplification, the geopolitical approach to energy security revolves around the notion of national interests and state-centered foreign policy action, turning energy into an instrument of political influence. Energy trade is seen as subordinate to hard power interests, and security planning prevails over market development. As such, it approximates to a large extent the realist view of international affairs, with its focus on state power and relative gains - as it is suspicious of the economic gains made by other states (Grieco, 1988) -, while the liberal view embraces the notion of prosperity based on absolute gains resulting from mutually advantageous economic arrangements (Axelrod and Keohane, 1985).

The nationalization of energy resources in energy exporting countries, especially in the 1960s and 1970s, and the creation of national state-controlled companies in the 
developing world have, as shown in the next section, strengthened state interventionism in energy matters.

The reality of international energy trade is not properly mirrored in either of these two extreme accounts, but rather has embraced hybrid forms of international energy systems imperfectly market-driven and incompletely state-controlled. For clarity, we focus on the international oil trade, although the arguments apply, with due qualifications and differentiations, to natural gas, coal, uranium or renewable energy technologies.

The paper also addresses the energy policies of the EU, which for more than two decades have been consistently liberal, rule-based, and nondiscriminatory, even as the international energy scene has seen a clear shift toward a realist approach, as aptly argued by Goldthau and Sitter (2015).

\section{Historical elements of the international oil trade}

After World War II until the mid-1970s, the international oil trade was dominated by an informal cartel of Anglo-Saxon companies that controlled about 85 percent of global oil reserves, as well as production, transport, refining and retail, to the result of effectively setting the oil price internationally. The cartel was pejoratively dubbed „Seven Sisters" ${ }^{1}$ by Mattei in the 1950s, back then head of Eni, the Italian state oil company, in frustration for his company's failure to be accepted in the Consortium for Iran, i.e. the group of seven international companies that had controlled the Middle Eastern oil production after the war, and were preparing to bring Iranian production back on the international market following the coup d'état of 1953, against Prime Minister Mohammed Mossadegh (Yergin, 2009).

With the significant exception of the Socialist bloc, world production was utterly privatized until the early 1960s. Another major exception was Pemex (Petroleos Mexicanos), built after the nationalization of oil producers in Mexico in 1938. As observed by Aguilera and Radetzky (2015, p.42),

"In the 1960s and 1970s, there followed a wave of nationalizations comprising Algeria, Iraq, Kuwait, Libya, Saudi Arabia and Venezuela among others..., so that by 1979, no less than 55 percent of non-Socialist world oil production had become government owned."

In 1960, the Organization of the Petroleum Exporting Countries (OPEC) was grounded in Baghdad, with the stated mission "to coordinate and unify the petroleum policies of its member countries and ensure the stabilization of oil markets, in order to secure an efficient, economic and regular supply of petroleum to consumers, a steady income to producers, and a fair return on capital for those investing in the petroleum industry.", as shown on OPEC's Website. In plain terms, OPEC was grounded as a

\footnotetext{
1 The Seven Sisters were Anglo-Iranian Oil Company (UK), Gulf Oil (US), Royal Dutch Shell (Netherlands/UK), Standard Oil of California (SoCal, US), Standard Oil of New Jersey (Esso, US), Standard Oil of New York (Socony, US), Texaco (US). After numerous mergers and acquisitions, four companies have survived to this day: ExxonMobil, BP, Chevron and Royal Dutch Shell. They are also known as the Supermajors.

Vol.11, No.3, Autumn, pp. 544-552, ISSN 1842-0206 | Management \& Marketing. Challenges for the Knowledge Society
} 
cartel with the mission of coordinating output levels among the member states in order to control the oil price internationally.

The cartel has not functioned efficiently at all. In order to use its weight on the upstream sector (exploration and production), OPEC instituted a production quota system, as a mechanism of coordinated restraint of oil output. Nonetheless, the individual quotas were never well grounded and mutually accepted, and never fully adhered to. As indicated by Aguilera and Radetzky $(2015,25)$,

"Quota discipline has been weak and cheating widespread. A comparison of actual OPEC output with the quota ceilings between 1983 and 2001 reveals that production exceeded the ceiling by 6.9 percent on average, with numerous occasions when the excess ran up to 15 percent or more. Production in excess of permitted quotas has continued after 2001. ...In fact, data over the past decades (IEA) show that, excepting for Saudi Arabia, Kuwait and UAE, virtually full technical capacity utilization has been the rule among OPEC members."

Apart from egoistic behavior in a typical collective action setting, the bitter political rivalries within OPEC go a long way explaining the cartel's dysfunction. OPEC has never succeeded in setting long-term price trends, but it has repeatedly achieved short-term market disruptions, especially on account of its main member's (Saudi Arabia) individual actions.

Thus, in October 1973, in response to the Western support for Israel in the Yom Kippur War, OPEC proclaimed an oil embargo, to the effect of sending up prices in a fourfold increase over the next six months, from $\$ 3$ to $\$ 12$ a barrel. Then, the Iranian Islamic Revolution of 1979 sent new shockwaves on the international oil markets: with a mere 4 percent cut of global production, prices more than doubled over the next year, reaching $\$ 39.5$ in early 1980 . The effect was compounded by the outbreak of the Iran-Iraq war in September 1980; until its end in August 1988, the war virtually ground to a halt oil output in the two OPEC's major producers.

The OECD countries were severely affected by the spiking oil prices. Economic recession hit the US and Western Europe in the 1970s and early '80s. However, against the backdrop of high prices, production outside OPEC grew significantly, so that between 1975 and 1985 demand for OPEC's oil shrank by more than 10 million barrels a day (mbd), i.e. about 20 percent of global output. The high prices of that decade led to market shrinkage and, starting with 1986, to sizeable price fall, which extended well into the 1990s and had, among its collateral effects, hit the ailing Soviet Union, accelerating its final collapse. At the same time, the pricing system shifted from OPEC's regulated prices to a market system operated by the two major mercantile exchanges, NYMEX (New York) and London Oil Exchange offer daily quotations of their respective oil benchmarks, WTI (West Texas Intermediate) and Brent.

All in all, from the early 1970 s to the mid 2010s, the oil price saw an unparalleled tenfold increase, reaching an absolute record of $\$ 147$ a barrel in June 2008. After a 60 percent fall in the aftermath of the financial crisis of 2008, the price gradually climbed back to over $\$ 100$, where a balance was maintained until mid 2014 . Then, from June 2014 to the early 2015, a renewed $60 \%$ fall took place, in a protracted 
slump that has reached its lowest point so far in February 2016, at $\$ 28$ a barrel of Brent.

The structural causes of the currently oversupplied market have to do, in the first place, with the shale revolution in North America, which turned the U.S. into the world's largest oil producer of the past few years, concomitantly with diminished demand from China. And again, Saudi Arabia has played a major catalytic role, with its decision to maintain high output in an oversupplied market, effectively declaring a commercial war for market share to all non-OPEC producers. In the process, though, many other producers within and outside OPEC have taken serious economic damages from the protracted low oil prices, with Russia, Venezuela, and Iran among them.

In a buyer's market such as today's one, energy security risk management has generally shifted from a mainly geopolitical to a more market-driven mode, though pockets of heightened geopolitical tensions have remained active in areas such as the Black Sea and the Baltic Basins - not to mention the Syrian theater of war.

Another characteristic of the present oil trade that has developed along with the waves of nationalizations in the oil and gas industry is the dominant presence of national oil companies (NOCs). Grounded on nationalized assets from the Western international oil companies (IOCs), and owning most of the planet's oil reserves and production volumes, the largest NOCs have, by and large, dwarfed IOCs in the global ranking of the largest oil companies.

Financial Times' Carola Hoyos put together in 2007 a list of the „New Seven Sisters," consisting of Saudi Aramco, Gazprom, China National Oil Corporation (CNPC), National Iranian Oil Corporation (Iran), PDVSA (Venezuela), Petrobras (Brasil), and Petronas (Malaysia). The market dynamics of the past of years has caused severe distress in some of these companies: de-capitalization in NIOC, PDVSA, and (more recently) Gazprom, as well as widespread corruption in Petrobras. However, the fact remains that 90 percent of global reserves and 75 percent of oil and gas production are currently in the hands of NOCs. Against this background, the IOCs have been reduced to the status of technology and operations management companies, thanks to their edge in know-how, research and human resources, as well as to their large pockets, that allow virtual financial independence in the development of their projects.

Based on their NOCs, both producing and consuming countries have, since the 1990s, turned to increasingly state-centered energy policies. The Russian Federation, for example, has blended its powerful energy export capacity with political and even military actions, thus contributing to the „securitization” of its energy trade with the $\mathrm{EU}$ and raising energy security to the level of a fundamental energy policy goal for Brussels, especially after the two Russian-Ukrainian "gas wars” of 2006 and 2009.

On the other hand, as the 2000s saw a swift accession of Asian emerging powers to the ranks of global energy consumers, Beijing has orchestrated the socalled „going out" policy by means of its NOCs, with the purpose of securing access to natural resources all around the globe - especially in Central Asia, Africa and South America. Thus, in the context of a tight market in the 2010s, with demand exceeding supply, the large emergent consumers simply did not trust the market forces as being able to account for their energy needs, while major exporters saw fit to use the 
favorable price context to strengthen the „power vertical” domestically and to make assertive claims internationally.

In a parallel development, the governments of hydrocarbons producing countries have almost invariably tended, in contexts of high prices, to revise the fiscal frameworks applied to the industry with the aim of capturing higher rents. Thus, a breed of short-term thinking oriented towards balancing state budgets and financing public spending has systematically curtailed the industry's ability to invest in new production capacities, to the effect of diminishing output. Therefore, unintentionally, governmental greed and shortsightedness has actually "functioned like an international cartel, constraining long-run supply." (Aguilera and Radetzky, 2015, p. 53).

Finally, a more recent factor shaping energy policy, in general, and the future of fossil fuels, in particular, is the corpus of energy policies and regulations related to the reduction of greenhouse gas (GHC) emissions, with the aim of limiting the ongoing global warming phenomenon to a ceiling of average temperature increase of 2C compared to the preindustrial level. Now, climate policies are typically perceived as dealing with market failures, i.e. with key social services in which the market has no incentives to invest. Accordingly, climate policy has emerged as a new area of state-led policy making, justifying sometimes swiping state interventions into the energy markets. Indeed, with a broad array of support schemes and bonuses, penalties and exemptions, state help of some form has become a condition for competitive advantage on the energy market for virtually every new power generation capacity.

Oil will likely remain the indispensable fuel in the transport sector for decades to come, although, here again, state-supported businesses and activities, such as electro-mobility, are starting to make a dent in gasoline's and diesel's largely unchallenged dominance. he first paragraph starts exactly at the left margin indentation none.

\section{The EU as a liberal actor on the international energy markets}

In an excellent recent book, Goldthau and Sitter (2015) analyze the paradoxical development of the EU as a liberal actor in energy matters in an international context increasingly dominated by the realist paradigm. After the Maastricht Treaty of 1992, the newly minted European Union undertook to extend the Single European Market (SEM) to the electricity and natural gas markets. EU-wide energy markets unification was to be achieved through detailed, rule-based integration, on open and competitive basis - an approach that went deeply against the grain of the monopolistic arrangement in place in most EU member states.

During the so-called „unipolar moment” of the 1990s, this was utterly in the spirit of the "Washington Consensus”, which was advocating for free markets as effective mechanisms of governance in the utilities sectors: electricity, gas and heating, water supplies, and telecommunications.

Through three successive Energy Market Packages, consisting of regulations and directives, Brussels has managed to largely deregulate EU's energy markets, to foster competition and transparency of tariffs and costs, to promote interconnectivity of grids, bidirectional gas flows, as well as put in place more competitive market models for both electricity and natural gas. Indeed, the liberalization of the EU 
internal market has proved, for all its insufficiencies, to be the most successful segment of Brussels's energy policies. It has progressed in parallel with state-centered energy foreign policy making, by which member states kept pursuing advantageous bilateral deals with external natural gas suppliers, even as the behavior of such suppliers was exacting costs from Eastern European member states.

As the liberal consensus was unraveling by the late 1990s, a zero-sum geopolitical game has resumed in a realist note that appeared brutal by contrast. As shown above, in the context of a very tight market in the mid-2000s, the two "gas wars" between Russia and Ukraine (which in hindsight proved to be mere precursors of the current political and military conflict between Moscow and Kiev) have acutely posed the question of EU's energy security and solidarity among member states. It was in the wake of those commercial and political spats that Brussels came to develop a plan of common foreign energy policy. Through February 2015's Energy Union Package, which put „energy security, solidarity and trust” as the first among the strategic document's dimensions, the European Commission tried to cope with the differing energy security concerns of Eastern and Western Europe.

There is no reason to expect converging interests in the following decades for various groups of EU member states. Both their apprehensions and sense of opportunities in relation to external powers differs according to their specific geographical situation, endowment of natural resources, market development, and historical experience. Nevertheless, somewhat ironically, the most effective energy security protection in Europe has come not from the rhetorically uplifting, yet practically inefficient proclamation of EU-wide solidarity, but from the rule-based, transparent and anti-monopolistic liberal development of its internal market legislation.

By design, the EU lacks both the means and the unity of strategic vision to counteract in kind the geopolitical undertakings of realist actors. In its foreign energy relations, the EU's liberal "genes" can be vindicated by its sheer market size and robustness of its rules. The EU cannot project hard power, as it has no significant one. The EU energy diplomacy basically consists in economic and climate diplomacy, oriented toward exports of clear energy technology, along with the creation of a global energy governance model that promotes a bold regime of GHG reduction. As observed by Richard Youngs (2007), the EU has in its foreign energy policy the tendency of extending upon its neighbors its acquis communautaire, in order to develop a common regulatory area with shared rules for energy trade, transit, and environmental protection.

For its uninterrupted supply with primary energy commodities, the EU has to rely on the hard power capabilities of other liberal actors - particularly on the foremost role of the United States - to make sure that oil, gas, coal, uranium etc. can find their way to the international markets, despite the numerous security threats facing the world today.

\section{Conclusion}

The market-based, liberal, and the state-centered, realist paradigms are the two ends of a spectrum of approaches to managing energy security risks. In reality, neither of these two paradigms is ever realized in pure form, although they have been closely 
approximated in particular historical junctures - the 1990s for the liberal paradigm, the 2000s for the realist one. Otherwise, hybrid forms of behavior have resulted out of the mixed state and corporate interests in maximizing energy security, economic gains, as well as in achieving other political goals.

Both energy producing and energy consuming states have found convenient to have a functional market regime, able to offer quick access, diversification and convenient prices. However, formal and informal cartels or monopolies have attempted to extract higher gains, albeit just for short timespans. NOCs have, at times, tried to emulate IOCs conduct on the capital markets and in terms of company management. However, they have served domestically as sources of cash for the governments' budgetary needs, and externally as foreign policy tools of their geopolitically minded patrons. At the same time, the realist power games prompted by high prices in the energy exporting countries have time and again been brought back to earth by price shocks, followed by painful adjustments of public spending. Moreover, governmental greed and shortsightedness, often elicited by public demands, lead to imposition of harsh fiscal terms on the upstream sector in times of high prices, to the effect of insufficient investments in capacity replacement and technology.

Finally, the EU is an atypical energy actor, of invariably liberal constitution in a world of increasingly realist complexion. Largely dependent on energy imports, the EU's approach to energy security has been to build up a rule-based, competitive and transparent internal market, in which external suppliers must act according to the rules. A rule-based environment will deprive them of the means to discriminate between markets and to exert inordinate political pressure.

On the other hand, EU's foreign energy policy is hardly able to deal with potential challenges from geopolitically assertive third parties and unstable external suppliers, as it lacks the needed unity of strategic vision and hard power.

\section{Disclaimer}

A shorter version of this article was presented during the 10th International Conference on Business Excellence in Energy, Climate Change and Sustainability (ICBE) in Bucharest, Romania, on the 3rd of March 2016, and published in the conference proceedings.

\section{References}

Axelrod, R. and Keohane, R. (1985), “Achieving Cooperation under Anarchy: Strategies and Institutions”, World Politics, Vol. 38, No. 1, pp. 226-254.

Goldthau, A. and Sitter, N. (2015), A Liberal Actor in a Realist World: The European Union Regulatory State and the Global Political Economy of Energy, London: Oxford University Press.

Grieco, J.M. (1988), “Anarchy and the Limits of Cooperation: A Realist Critique of the Newest Liberal Institutionalism”, International Organization, Vol. 42, No. 3, pp. 485-507.

Hoyos, C. (2007), “The New Seven Sisters: Oil and Gas Giants Dwarf Western Rival” Financial Times, March 12. 
MMCKS Van der Linde, C. (2008), “Managing Energy Security Risk in a Changing World” in Paul Bracken, Ian Bremmer and David Gordon (eds.), Managing Strategic Surprise. Lessons from Risk Management and Risk Assessment, Cambridge University Press.

Shaffer, B. (2009), "Energy Politics", University of Pennsylvania Press.

Noel, P. (2008), "Challenging the Myths of Energy Security", Financial Times, January 10.

Yergin, D. (2009), “The Prize. The Epic Quest for Oil, Money and Power", Free Press.

Youngs, R. (2007), "Europe's External Energy Policy: Between Geopolitics and the Market" CEPS Working Document, No. 278, Brussels, November. 